Cell Differentiation, 5 (1976) 83-96

(c) North-Holland Publishing Company, Amsterdam - Printed in The Netherlands

\title{
THE EFFECT OF SV40 TRANSFORMATION ON THE CHROMOSOMAL PROTEINS OF 3T3 MOUSE EMBRYO FIBROBLASTS
}

\author{
M.O. KRAUSE ${ }^{1}$, K.D. NOONAN ${ }^{1}$, L.J. KLEINSMITH ${ }^{2}$ and G.S. STEIN ${ }^{1}$ \\ ${ }^{1}$ Department of Biochemistry, University of Florida, Gainesuille, Fla. 32610; \\ ${ }^{2}$ Department of Zoology, University of Michigan, Ann Arbor, Mich. 48104, U.S.A.
}

Accepted 19 April 1976

The composition and metabolism of chromosomal proteins - histones and nonhistones chromosomal proteins - were examined in normal and SV40 transformed 3T3 mouse cells. Variations were observed, many of which were similar to those previously reported for normal and SV40 transformed WI38 human diploid fibroblasts. The possible implications of these viral induced changes in the protein component of the genome for the phenotypic modifications which occur in transformed cells are discussed.

Tranformation of mammalian cells by SV 40 virus results in phenotypic changes which are evident at the morphological as well as biochemical levels (Bull et al., 1974; Butel et al., 1971; Sakiyama et al., 1972; Yogeeswaran et al., 1972). Elucidating the manner in which the expression of viral information, integrated within the host cell genome, is regulated is central to understanding the mechanism by which maintenance of the transformed state is acieved. Since chromosomal protein - histone and non-histone chromosomal proteins - play a key role in the regulation of transcription (Allfrey et al., 1963; Huang et al., 1965; Gilmour et al., 1970; Kleinsmith et al., 1970; Spelsberg et al., 1970; Teng et al., 1971; Kostraba et al., 1973; Paul et al., 1973; Stein et al., 1972a, b, 1974b, 1975, and in press) as well as in the determination of chromatin structure (Allfrey, 1971; Clark et al., 1971; Hnilica et al., 1971; Hewisch et al., 1973; Noll, 1974; Kornberg, 1974; Kornberg et al., 1974; Rill et al., 1973; Krause et al., 1974c; Olins et al., 1974; Stein et al., 1974; Weintraub et al., 1974a), it is reasonable to anticipate the potential involvement of these proteins in mediating viral-induced modifications in gene readout.

Several laboratories have recently reported complex alterations in the composition and metabolism of both histones and nonhistone chromosomal proteins of SV40 transformed WI38 human diploid fibroblasts (Zardi et al., 1973; Cholon et al., 1974; Lin et al., 1974; Krause et al., 1974, 1975a, $\mathrm{b}, \mathrm{c})$. In the present studies we examined the chromosomal proteins of nor-

\footnotetext{
* Permanent address: Department of Biology, University of New Brunswick, Fredericton, Canada.
} 
mal and SV40 transformed 3T3 mouse cells to establish if any or all of the detected alterations might be a generalized feature of SV40 tranformation.

\section{MATERIALS AND METHODS}

\section{Cell culture}

NIH/Swiss 3T3 mouse embryo fibroblasts and an SV40 transformed population derived from the parental clone were grown in monolayer culture in Dulbecco Modified Eagle's Medium (DMEM) containing 10\% calf serum. The cells were cultivated in $150 \times 15 \mathrm{~mm}$ plastic petri dishes and incubated in a moist $\mathrm{CO}_{2}$ incubator. All experiments were carried out utilizing exponentially growing normal and SV40 transformed cells. To ensure exponential growth of $3 \mathrm{~T} 3$ cells, $2 \%$ serum was added to the cultures $20 \mathrm{~h}$ before harvest.

\section{Labelling with radioisotopes}

A. Labelling with ${ }^{3} \mathrm{H}$ leucine. Medium was removed from each petri and replaced with $10 \mathrm{ml}$ of L-leucine-free DMEM containing L-leucine- ${ }^{3} \mathrm{H}(5 \mu \mathrm{Ci}$ / $\mathrm{ml}, 41.2 \mathrm{Ci} / \mathrm{mM}$ ) and $2 \%$ fetal calf serum. To study the effect of an inhibitor of DNA synthesis on chromosomal protein metabolism, parallel cultures were incubated with $40 \mu \mathrm{g} / \mathrm{ml}$ of cytosine arabinoside for $15 \mathrm{~min}$ prior to labelling and throughout the $2 \mathrm{~h}$ labelling period. Each sample consisted of 1.5 $\times 10^{7}$ cells. Isotope incorporation was terminated by pouring off the labelling medium and washing the monolayers three times with $15 \mathrm{ml}$ of cold $\left(4^{\circ} \mathrm{C}\right)$ Earle's Balanced Salt Solution.

B. Labelling with L-tryptophan ${ }^{3} \mathrm{H}$ and ${ }^{32} \mathrm{P}$. For double labelling experiments, medium was removed from the monolayer cultures and cells in each petri were incubated for $60 \mathrm{~min}$ with $10 \mathrm{ml}$ of L-tryptophan-free DMEM containing L-tryptophan ${ }^{3} \mathrm{H}(5 \mu \mathrm{Ci} / \mathrm{ml}, 1.65 \mathrm{Ci} / \mathrm{mM}),{ }^{32} \mathrm{P}(100 \mu \mathrm{Ci} / \mathrm{ml})$ and $2 \%$ fetal calf serum. Each sample consisted of $1.5 \times 10^{7}$ cells. Isotope incorporation was terminated and monolayers were washed as described above. All isotopes were obtained from New England Nuclear Corporation, Boston, Massachusetts.

\section{Isolation of nuclei}

Preparation of nuclei was carried out at $4^{\circ} \mathrm{C}$. Details of the procedure have been described (Stein et al., 1973). Cells were harvested by scraping with a rubber policeman, washed three times with Earle's Balanced Salt Solution and lysed with $80 \mathrm{mM} \mathrm{NaCl}-20 \mathrm{mM}$ EDTA-1\% Triton X-100 (pH 7.2). Nuclei were pelleted by centrifugation at $1000 \mathrm{~g}$ for $4 \mathrm{~min}$ and washed three times with the lysing medium. This was followed by two washes with $0.15 \mathrm{M}$ 
$\mathrm{NaCl}-0.01 \mathrm{M}$ Tris (pH 8.0). Nuclei isolated in this manner are free of cytoplasmic contamination when examined by phase contrast microscopy. Since we observed that in 3T3 cells proteolytic degradation occurs under these conditions, cell lysis and washing of nuclei were carried out in the presence of $50 \mu \mathrm{g} / \mathrm{ml}$ of L-1-tosylamide-2-phenyl-ethyl-chloromethyl-ketone (TPCK), except where indicated.

Extraction of histones. Histones were extracted from isolated nuclei of normal and SV 40 transformed $3 \mathrm{~T} 3$ cells at $4^{\circ} \mathrm{C}$ with $0.25 \mathrm{~N} \mathrm{HCl}$. Nuclei isolated from $2 \times 10^{7}$ cells were suspended in $2 \mathrm{ml}$ of $\mathrm{HCl}$ and agitated by shaking for $20 \mathrm{~h}$. They were then pelleted by centrifugation at $6000 \mathrm{~g}$ for $15 \mathrm{~min}$, reextracted for an additional $30 \mathrm{~min}$ with $1 \mathrm{ml}$ of $0.25 \mathrm{~N} \mathrm{HCl}$ and pelleted in the same way. The combined dilute mineral acid extracts were precipitated by addition of 9 volumes of acetone. After $12 \mathrm{~h}$ the precipitates were pelleted by centrifugation at $15,000 \mathrm{~g}$ for $15 \mathrm{~min}$, washed with $5 \mathrm{ml}$ acetone, $5 \mathrm{ml}$ of ether and dried under vacuum.

\section{Polyacrylamide gel electrophoresis of total chromosomal proteins}

Isolated nuclei were dissociated by homogenization in $1.5 \mathrm{ml}$ of $1 \%$ SDS$1 \% \beta$-mercaptoethanol-0.01 $\mathrm{M}$ sodium phosphate $(\mathrm{pH} 7.0)$ in a Dounce homogenizer fitted with a 'tight' pestle. They were then heated for $3 \mathrm{~min}$ in a boiling water bath, cooled to room temperature and dialyzed overnight against $0.1 \%$ SDS- $0.1 \% \beta$-mercaptoethanol- $0.01 \mathrm{M}$ sodium phosphate $(\mathrm{pH}$ 7.0 ), at $22^{\circ} \mathrm{C}$. Sucrose was added to a final concentration of $15 \%$. Such treatment of chromosomal proteins results in irreversible denaturation of endogenous proteases as evidenced by the absence of modifications when samples are maintained at room temperature for several days. $50 \mu \mathrm{l}$ aliquots, containing approximately $25 \mu \mathrm{g}$ of chromosomal proteins, were electrophoresed on $0.6 \times 7.5 \mathrm{~cm}, 7.5 \%$ polyacrylamide gels containing $0.1 \%$ SDS. A $0.6 \times 2 \mathrm{~cm}$, $2.5 \%$ stacking gel containing $0.1 \%$ SDS was used. Electrophoresis was carried out for $7 \mathrm{~h}$ at $8 \mathrm{~mA}$ per gel in a running buffer of $0.1 \%$ SDS $-0.1 \mathrm{M}$ sodium phosphate $-5 \mathrm{mM}$ EDTA ( $\mathrm{pH} 7.0$ ). Details of the procedure have been reported (Krause et al., 1975 a, b). Following completion of electrophoresis, gels were immediately removed from the glass tubes, fixed in $12 \%$ trichloroacetic acid $-40 \%$ ethanol- $7 \%$ acetic acid at $22^{\circ} \mathrm{C}$ for $12 \mathrm{~h}$, and stained with $0.25 \%$ Coomassie brilliant blue in $40 \%$ ethanol- $7 \%$ acetic acid at $22^{\circ} \mathrm{C}$ for $5 \mathrm{~h}$. Gels were then washed with $40 \%$ ethanol- $7 \%$ acetic acid and electrophoretically destained in a Canalco 'Quick gel' destainer using $10 \%$ ethanol$7 \%$ acetic acid as buffer. Gels were stored in $7 \%$ acetic acid.

Polyacrylamide gel electrophoresis of histones. Histones were fractionated on $0.6 \times 9 \mathrm{~cm}, 15 \%$ polyacrylamide gels containing $2.5 \mathrm{M}$ urea according to the method of Panyim et al. (1969). 20-40 $\mu \mathrm{g}$ of histones $(1 \mathrm{mg} / \mathrm{ml}$ in $0.9 \mathrm{M}$ acetic acid, $15 \%$ sucrose) were applied to each gel. Electrophoresis was car- 
ried out for $4 \mathrm{~h}$ at $2 \mathrm{~mA} /$ gel using $0.9 \mathrm{M}$ acetic acid as the tray buffer. Histone gels were stained overnight in $0.1 \%$ amido black $-20 \%$ ethanol $-7 \%$ acetic acid and destained for $\mathbf{1 5}$ min in a Canalco 'quick' gel destainer.

Analysis of the gels. Both histone and total chromosomal protein gels were scanned $(600 \mathrm{~nm})$ shortly after destaining in a Beckman Acta II spectrophotometer equipped with a linear gel transport. The areas under the scan were integrated with a planimeter to determine the relative amounts of protein in each band in the case of acetic acid-urea gels of histones or in discrete molecular weight regions in the case of SDS gels of total chromosomal proteins.

Standard curves were constructed relating areas integrated vs. $\mu \mathrm{g}$ of protein as determined by the method of Lowry (Lowry et al., 1951). For Coomassie blue a mixture of acidic and basic proteins was used as a reference. For amido black stained gels calf thymus histone served as a reference. In both cases the amount of stain bound (absorption) varied in a linear fashion with the protein concentration applied to the gels.

After scanning, each gel was frozen in dry ice, fractionated into $1 \mathrm{~mm}$ slices, each slice was placed in a liquid scintillation counting vial containing $0.2 \mathrm{ml}$ of $30 \% \mathrm{H}_{2} \mathrm{O}_{2}$ and the gel slices were solubilized by heating at $37^{\circ} \mathrm{C}$ for $12 \mathrm{~h}$. Fractions containing preidentified bands were marked to facilitate correlating the absorbance scans with the radioactivity profiles. The fractions were counted in a Triton X-100-toluene--liquifluor $(1: 2: 0.126)$ cocktail in a Nuclear Chicago Isocap-300 liquid scintillation spectrometer. Corrections for ${ }^{32} \mathrm{P}$ spillover in double labelled samples were calculated by means of prepared standards.

\section{RESULTS}

Nonhistone chromosomal proteins of normal and SV4O transformed $3 T 3$ cells

Initially the chromosomal proteins of normal and SV40 transformed 3T3 cells were examined by electrophoretic fractionation according to molecular weight on SDS polyacrylamide gels. The polyacrylamide gel electrophoretic banding patterns are illustrated in Fig. 1. Major bands are identified alphabetically in the order of the highest to the lower molecular weight. Peaks A-H and $\mathrm{J}$ represent nonhistone chromosomal proteins while peaks $\mathrm{I}, \mathrm{K}, \mathrm{L}$, and $\mathrm{M}$ represent histone fractions $\left(\mathrm{I}=\mathrm{H}_{1}, \mathrm{~K}=\mathrm{H}_{3} \& \mathrm{H}_{2} \mathrm{~b}, \mathrm{~L}=\mathrm{H}_{2} \mathrm{a}\right.$, and $\left.\mathrm{M}=\mathrm{H}_{4}\right)$. Furthermore, six molecular weight regions were arbitrarily selected for comparison and molecular weight boundaries for each region were calculated using 4 marker proteins; phosphorylase A (94,000 daltons), bovine serum albumin (68,000 daltons), myoglobin $(14,200$ daltons), and cytochrome $\mathrm{C}(12,400$ daltons). Nonhistone chromosomal protein peaks $B, F^{\prime}, G^{\prime}, G$ and $H$ are more pronounced in SV40 transformed cells while components of the high 


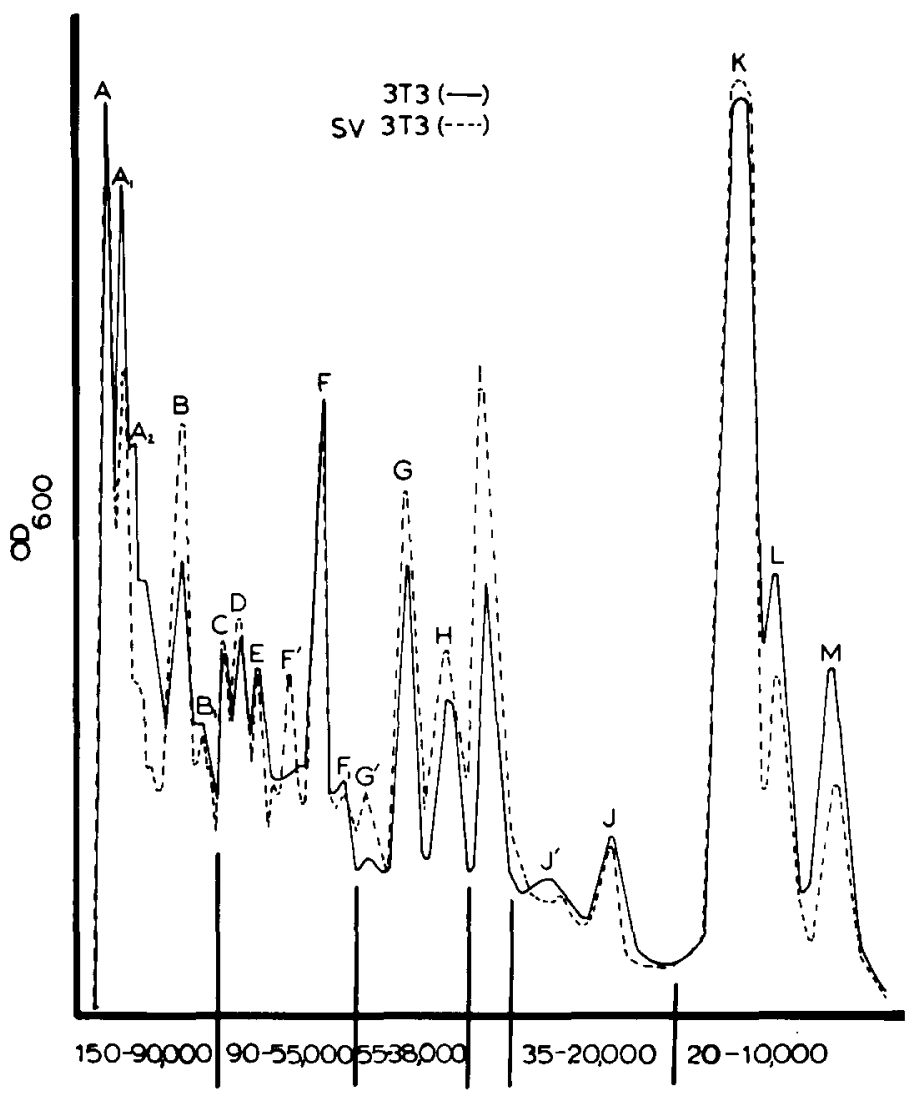

Fig. 1. SDS polyacrylamide gel electrophoretic banding pattern of chromosomal proteins from normal and SV40 transformed 3T3 mouse cells. $25 \mu \mathrm{g}$ of protein were applied to each gel: the gels were electrophoresed for $7 \mathrm{~h}$ at $8 \mathrm{~mA} / g e l$, fixed, stained and scanned as described in Materials and Methods. 23 discrete bands were identified in alphabetical order from high to low molecular weight. The areas under the scan were integrated in order to estimate relative protein content in the five arbitrarily selected molecular weight sections of the gels.

molecular weight A-complex are more pronounced in normal 3T3 cells. The relative amounts of protein present in the various molecular weight regions of the gel, in both normal and SV40 transformed 3T3 cells, are presented in Table I. The nonhistone chromosomal protein : histone ratios in normal and SV40 transformed cells are similar. However, consistent with variations in specific nonhistone chromosomal peaks between normal and SV40 transformed cells, some differences are apparent in the relative amounts of protein in defined molecular weight regions.

Preparation of nuclei in the absence of protease inhibitors does not significantly affect the recovery of histones from normal (Fig. 2a) or SV40 transformed 3T3 cells (Fig. 2b). In contrast, protease inhibitors are required to prevent loss of a broad molecular weight spectrum of nonhistone chromo- 


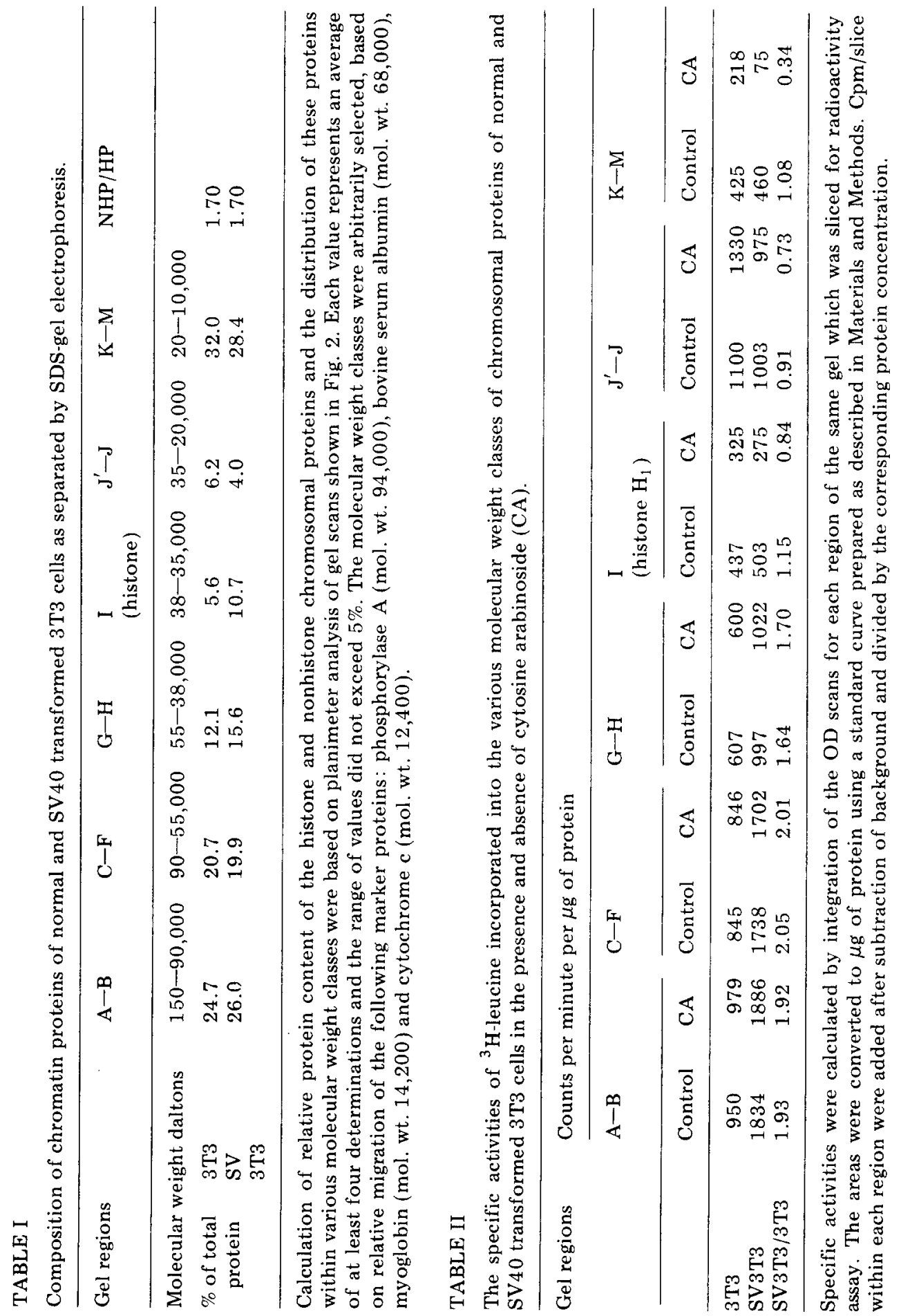


somal proteins from normal as well as SV40 transformed 3T3 cells. When TPCK is used, both cell types exhibit an increased recovery of nonhistone chromosomal proteins which migrate in the 38,000-90,000 dalton regions of SDS gels (peak ' $F$ ' excluded). In SV 40 transformed cells, a preferential recovery of $38,000-55,000$ dalton nonhistone chromosomal proteins is apparent, while in normal 3T3 cells polypeptides of a molecular weight greater than 100,000 daltons are selectively retained (the A-complex). The overall loss of nonhistone chromosomal proteins from nuclei prepared in the absence of TPCK is greater in SV40 transformed than in normal 3T3 cells. It should also be noted that in SV40 transformed cells, the rate at which high molecular weight nonhistone chromosomal protein recovery decreases in the absence of protease inhibitors is greater (data not shown).

Metabolism of chromosomal proteins in normal and SV40 transformed $3 T 3$ cells

A. Synthesis and coupling with DNA replication. The rates of nonhistone chromosomal protein synthesis in normal and SV40 transformed 3T3 cells

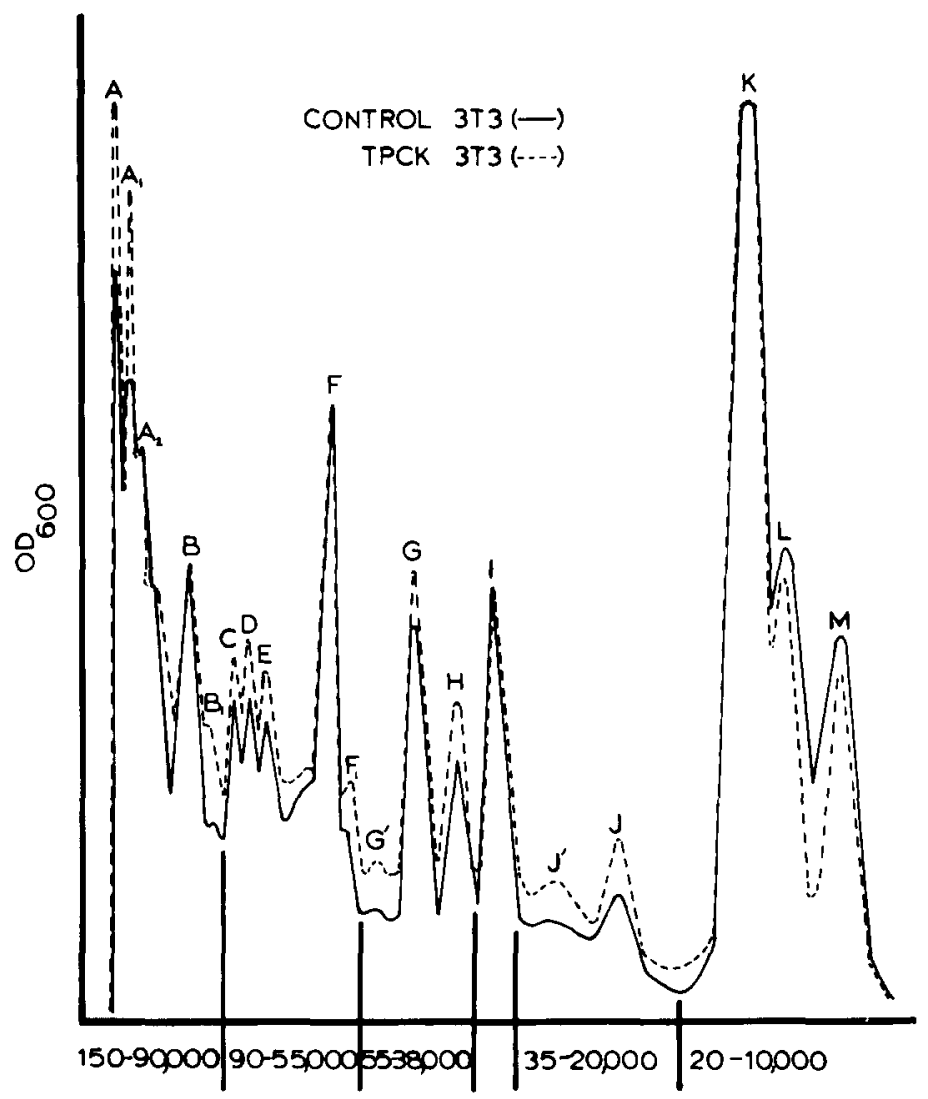




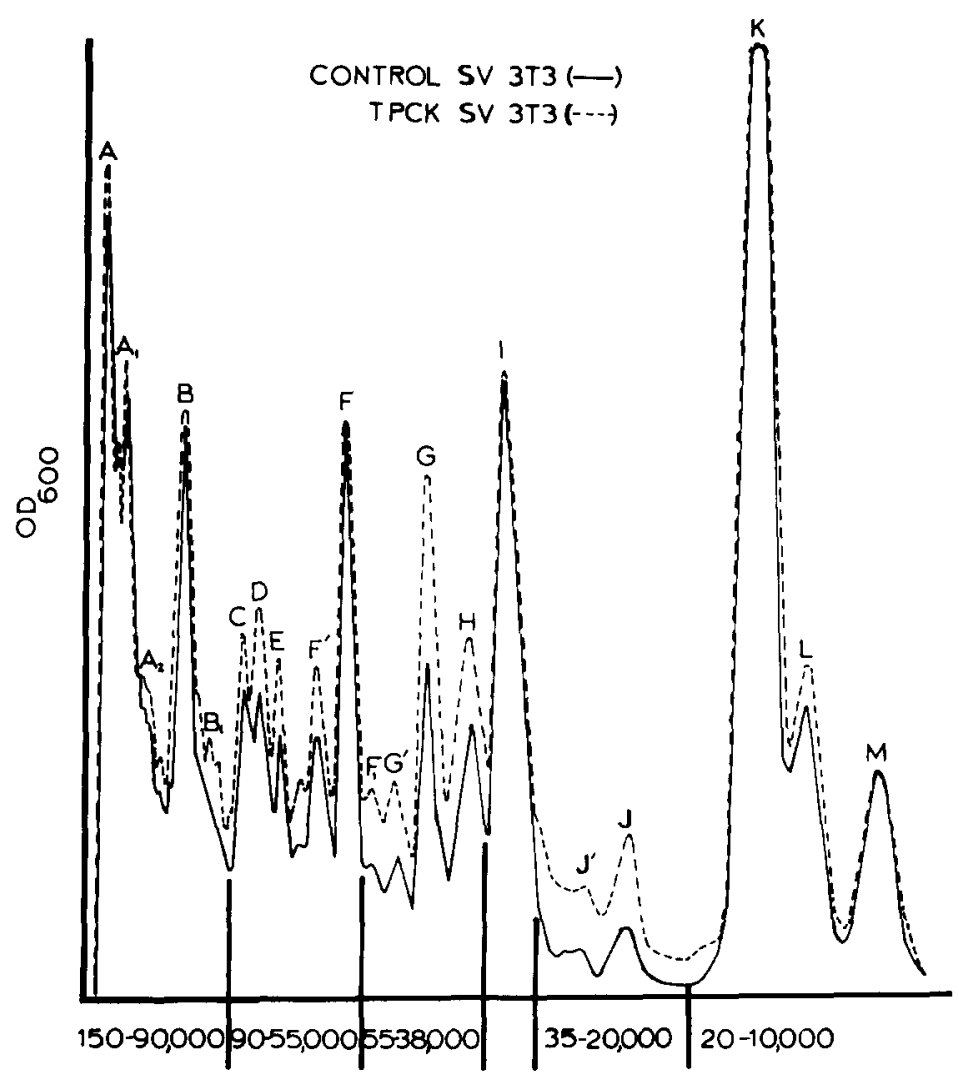

Fig. 2. The effect of proteolytic inhibitor (TPCK), on the protein content of discrete bands of nonhistone polypeptides from normal (A) and SV40 transformed (B) 3T3 mouse cells. TPCK was present at a concentration of $50 \mu \mathrm{g} / \mathrm{ml}$ during cell lysis and purification of nuclei as described in Materials and Methods (-...-). In control samples these procedures were carried out in the absence of the inhibitor (- - ).

were compared by pulse-labelling with L-leucine- ${ }^{3} \mathrm{H}$ and fractionating the chromosomal proteins electrophoretically according to molecular weight on SDS polyacrylamide gels. The data in Table II indicate that in SV 40 transformed cells, significant increases (1.6-2-fold) in the specific activities on nonhistone chromosomal proteins which migrate in regions $\mathrm{A}-\mathrm{B}, \mathrm{C}-\mathrm{F}$, and $\mathrm{G}-\mathrm{H}$ are apparent. While the rates of synthesis of chromosomal proteins from normal and SV40 transformed cells which electrophorese in regions $\mathrm{I}$ and $\mathrm{K}-\mathrm{M}$ are similar, interpretation of these data is complex since histones as well as some nonhistone chromosomal proteins are found here.

To examine the relationship between nonhistone chromosomal protein synthesis and DNA replication, parallel cultures of normal and SV40 transformed 3T3 cells were pretreated for $15 \mathrm{~min}$ with cytosine arabinoside and then pulse-labelled with L-leucine- ${ }^{3} \mathrm{H}$ in the presence of the inhibitor. It 
should be noted that the concentration of cytosine arabinoside used in these studies inhibits DNA synthesis in normal as well as in SV40 transformed $3 \mathrm{~T} 3$ cells by $96 \%$. There is no significant effect of cytosine arabinoside on the specific activity of nonhistone chromosomal proteins which migrate in regions $\mathrm{A}-\mathrm{B}, \mathrm{C}-\mathrm{F}$ and $\mathrm{G}-\mathrm{H}$ of SDS polyacrylamide gels. The cytosine arabinoside inhibition which is evident in the 10,000-20,000 and 35,00038,000 dalton regions is attributable primarily to histones. However, the extent to which histone synthesis is inhibited cannot be accurately determined from these data due to the presence of low molecular weight, nonhistone chromosomal proteins.

B. Synthesis and phosphorylation of nonhistone chromosomal proteins. The synthesis and phosphorylation of nonhistone chromosomal proteins in normal and SV40 transformed 3T3 cells were studied by pulse-labelling cells with a mixture of L-tryptophan ${ }^{3} \mathrm{H}$ and ${ }^{32} \mathrm{P}$ and then electrophoretically fractionating chromosomal proteins on SDS polyacrylamide gels. Consistent with the increased rate of synthesis of high molecular weight, nonhistone chromosomal proteins $(38,000-150,000$ daltons), observed in SV40 transformed cells when leucine- ${ }^{3} \mathrm{H}$ was used as a label, a 1.6-2.4-fold increased specific activity in these polypeptides of SV40 transformed cells is evident when the label is tryptophan ${ }^{3} \mathrm{H}$ (Table III). The data in Table III also clearly indicate that the rate of phosphorylation of nonhistone chromosomal proteins which migrate in regions $\mathrm{A}-\mathrm{B}, \mathrm{C}-\mathrm{F}$, and $\mathrm{G}-\mathrm{H}$ is more pronounced in SV40 transformed than in normal 3T3 cells. Again, calculations of specific activities of nonhistone chromosomal proteins in the $10,000-38,000$ dalton region of SDS gels are complicated by the presence of histones. This is particularly a problem in the present experiments since while histones account for the major protein contents of regions $\mathrm{I}$ and $\mathrm{K}-\mathrm{M}$, histones lack tryptophan residues and nonhistone chromosomal proteins exhibit a greater extent of phosphorylation.

C. Synthesis and phosphorylation of histones in normal and SV4O transformed $3 T 3$ cells. The synthesis and phosphorylation of histones in normal and SV40 transformed 3T3 cells were studied by pulse-labelling cells with a mixture of L-leucine- ${ }^{3} \mathrm{H}$ and ${ }^{32} \mathrm{P}$, extracting histones from isolated nuclei for $20 \mathrm{~h}$ with $0.25 \mathrm{~N} \mathrm{HCl}$ and then fractionating the histones electrophoretically on acetic acid-urea polyacrylamide gels, according to the method of Panyim and Chlakley (1969). The data in Table IV indicate that the relative amounts of individual histone fractions $\left(\mathrm{H}_{1}, \mathrm{H}_{3}, \mathrm{H}_{2 \mathrm{~b}}, \mathrm{H}_{2 \mathrm{a}}\right.$ and $\left.\mathrm{H}_{4}\right)$ recovered from normal and SV40 transformed cells are similar. However, differences between normal and SV40 transformed cells are evident with respect to rates of synthesis and extent of phosphorylation of specific fractions.

The ratio of the synthetic activities of $\mathrm{H}_{1}$ and $\mathrm{H}_{2 \mathrm{a}}$ appears to vary in an inverse proportion to their respective phosphorylation rates in normal and SV40 transformed $3 \mathrm{~T} 3$ cells. While the specific activity ratio of $\mathrm{H}_{1} / \mathrm{H}_{2 \mathrm{a}}$ for 


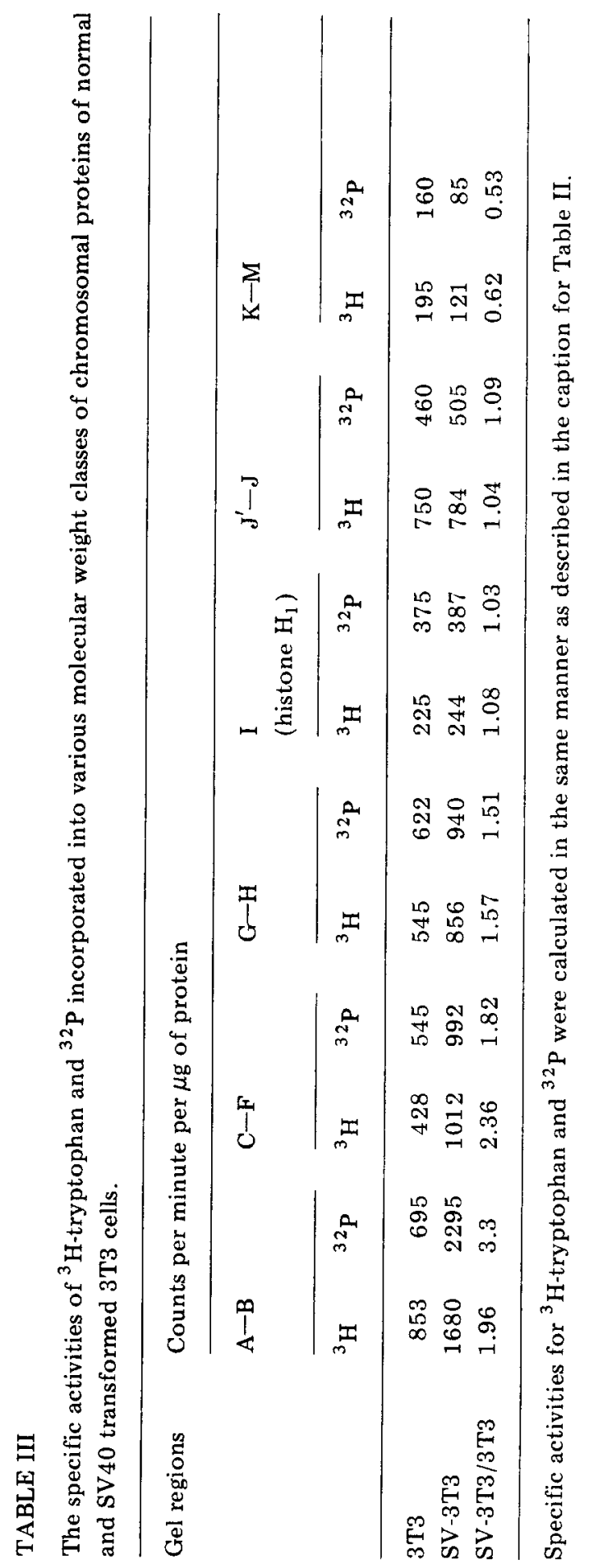


TABLE IV

The incorporation of ${ }^{3} \mathrm{H}$-leucine and ${ }^{32} \mathrm{P}$ into histones of normal and SV40 transformed 3 T3 cells fractionated in urea-acetic acid gels.

\begin{tabular}{|c|c|c|c|c|c|c|}
\hline \multirow[t]{2}{*}{ Fractions } & \multicolumn{3}{|l|}{ 3T3 } & \multicolumn{3}{|l|}{ SV-3T3 } \\
\hline & $\%$ Protein & $\begin{array}{l}{ }^{3} \mathrm{H} \\
(\mathrm{cpm} / \mu \mathrm{g})\end{array}$ & $\begin{array}{l}{ }^{32} \mathrm{P} \\
(\mathrm{cpm} / \mu \mathrm{g})\end{array}$ & $\%$ Protein & $\begin{array}{l}{ }^{3} \mathrm{H} \\
(\mathrm{cpm} / \mu \mathrm{g})\end{array}$ & $\begin{array}{l}{ }^{32} \mathrm{P} \\
(\mathrm{cpm} / \mu \mathrm{g})\end{array}$ \\
\hline $\mathrm{H}_{1}$ & 14 & 248 & 272 & 14 & 310 & 328 \\
\hline $\mathrm{H}_{3}$ & 22 & 626 & - & 25 & 476 & - \\
\hline $\mathrm{H}_{2 \mathrm{~b}}$ & 30 & 584 & - & 26 & 422 & - \\
\hline $\mathrm{H}_{2 \mathbf{a}}$ & 13 & 330 & 120 & 17 & 750 & 80 \\
\hline $\mathrm{H}_{4}$ & 21 & 181 & - & 18 & 362 & - \\
\hline $\mathrm{H}_{1} / \mathrm{H}_{2 \mathrm{a}}$ & 1.1 & 0.75 & 2.26 & 0.8 & 0.41 & 4.1 \\
\hline $\mathrm{H}_{3} / \mathrm{H}_{4}$ & 1.05 & 3.45 & - & 1.4 & 1.31 & - \\
\hline
\end{tabular}

Protein concentrations and specific activities for each histone fraction were calculated as described for Tables II and III using the same gel for both OD scan and radioactivity assay.

${ }^{3} \mathrm{H}$-leucine is almost twice as high in normal as in SV40 transformed cells, the same ratio for ${ }^{32} \mathrm{P}$ incorporation is almost twice as high in transformed as in normal 3T3 cells. The ratio of the synthetic activities of the 2 argininerich histones, $\mathrm{H}_{3} / \mathrm{H}_{4}$, also differs markedly. The specific activity of $\mathrm{H}_{3}$ is significantly decreased while that of $\mathrm{H}_{4}$ is doubled in SV40 transformed cells, as compared with normal $3 \mathrm{~T} 3$ cells.

\section{DISCUSSION}

The present studies indicate that there are differences in the composition and metabolism of nonhistone proteins of normal and SV40 transformed 3T3 mouse cells. Some of these differences appear to be consistent with those reported in association with normal and SV40 transformed WI38 human diploid fibroblasts (Zardi et al., 1973; Cholon et al., 1974; Lin et al., 1974; Krause et al., 1974, 1975a, b, c).

Observed variation in the relative protein content of specific molecular weight classes of nonhistone polypeptides may be ascribed to SV40 transformation in different cell types. For example, peaks B (105,000 daltons), $\mathrm{H}(48,000$ daltons) and I ( 36,000 daltons) are consistently more pronounced after SV40 transformation in both human WI38 and mouse 3T3 cells. Because peak $\mathrm{I}$ is known to contain histone $\mathrm{H}_{1}$, the effect might be due to nonhistone polypeptides comigrating with $\mathrm{H}_{1}$ in this region. Such a view is supported by the results obtained with isolated histones since the high ratio of $\mathrm{I} / \mathrm{K}-\mathrm{M}$ observed in SDS gels of SV-3T 3 chromosomal proteins (Table I) is not paralleled by a similar rise in the protein content of the $\mathrm{H}_{1}$ fraction relative to other histones (see Table IV). Variations observed in the nonhistone chromosomal proteins of normal and SV 40 transformed cells are most likely 
not attributable to serine proteases since such differences in chromosomal polypeptides are evident when nuclei and chromatin are prepared in the presence of TPCK, a serine protease inhibitor. The possibility cannot be completely eliminated that differences in the chromosomal proteins of normal and SV40 transformed cells may in part be attributable to non-serine proteases. However, the stability of chromosomal proteins of normal and SV 40 transformed cells isolated in the presence of TPCK argues against the latter alternative.

The present results also demonstrate that the overall loss of nonhistone chromosomal proteins prepared in the alsence of a proteolytic inhibitor (TPCK) is greater in SV40 transformed than in normal 3T3 cells. One possible interpretation of this finding is that SV40 transformed 3T3 cells exhibit higher levels of protease activity. The occurrence of increased proteolytic activity in transformed cells would not be unprecedented. It has been proposed that proteolytic activity is linked to the cleavage of cell surface constituents which occurs concomitantly with loss of contact inhibition (Goldberg, 1974). If in fact the loss of chromosomal proteins in SV40 transformed 3T3 cells can be directly shown to result from proteolysis, it would remain to be established whether this loss reflects a general increase in cellular proteolytic activity or whether it indicates the synthesis and/or activation of proteases which preferentially utilize chromosomal proteins as substrates.

Another finding in these studies which is consistent with that reported for WI38 cells, is the increased rates of synthesis and phosphorylation of nonhistone chromosomal proteins in transformed compared to normal cells (Krause et al., $1975 \mathrm{a}$, b). While it is possible that pool size differences may in part contribute to the observed difference in specific activities, the differential effects observed in different molecular weight classes of proteins makes this an unlikely explanation of the results. In the human as well as in the mouse cells the most pronounced increased synthesis is apparent in the nonhistone chromosomal polypeptides which migrate in the 55,000-90,000 dalton regions of SDS polyacrylamide gels.

The observed differences in the rates of synthesis of some histone fractions can be interpreted on the basis of their strength of binding in chromatin. The method of isolation of nuclei used in the present experiments has been shown to be selective for retention of lysine-rich histones while conserving only a portion of the arginine-rich fractions, particularly those newly synthesized proteins (Krause et al., 1974c, 1975c). Therefore, apparent variations in the rates of synthesis of arginine-rich histones in normal and SV40 transformed 3T3 cells may be due, at least in part, to differences in binding of the newly synthesized species (Krause et al., 1974a). Such variations are consistent with differences in the extractability of $\mathrm{H}_{3}$ and $\mathrm{H}_{4}$ fractions in normal and SV40 transformed WI38 human diploid fibroblasts (Krause et al., 1975c). Although Gonzalez and Rees (1975) did not find significant modifications in the chromosomal proteins of normal and SV40 transformed 3T3 cells, the discrepancy between their results and ours may be attributable to 
differences in isolation and fractionation techniques employed by the two laboratories.

To establish the functional significance of the changes observed in the protein component of the genome in cells transformed by SV40 several points must be considered. First, it has not been experimentally determined whether the newly synthesized proteins are coded for by host cell or integrated viral genetic sequences. However, the limited amount of viral genetic information virtually eliminates the possibility that these newly synthesized chromosomal proteins of SV40 transformed cells are directly encoded in the viral DNA. It is also unclear whether the additional chromosomal proteins which appear in SV40 transformed cells are associated with host cell or integrated viral DNA. Since chromosomal proteins dictate structural and transcriptional properties of the genome answers to questions such as these are important for understanding the transcriptional component of viral induced alterations in gene expression and their phenotypic manifestations in SV40 transformed cells.

\section{ACKNOWLEDGEMENTS}

These studies were supported by the following research grants: GB38349 and BMS7423418 from the National Science Foundation, GM20535 from the National Institutes of Health, A4433 from the National Research Council of Canada and DRG-1241 from the Damon Runyon-Walter Winchell Cancer Foundation.

\section{REFERENCES}

Allfrey, V.G.: In: Histones and Nucleohistones; ed. D.M.P. Phillips (Plenum Press, New York) p. 241(1971).

Allfrey, V.G., U. Littau and A.E. Mirsky: Proc. Nat. Acad. Sci. U.S.A. 49, 419 (1963).

Barrett, T., D. Maryanka, P.H. Hamlyn and H.J. Gould: Proc. Nat. Acad. Sci. U.S.A. 71, 5057 (1974).

Bull, D., A.T. Taylor, D.M. Austin and O.H. Jones: Virology 57, 279 (1974).

Butel, J.S., S.S. Teuethia, N. Biswal and M. Benyesh-Melnick: In Vitro 6, 335 (1971).

Cholon, J.J. and G.A. Studzinski: Cancer Res. 34, 588 (1974).

Clark, R.J. and G. Felsenfeld: Nature New Biol. 229, 101 (1971).

Gilmour, R.S. and J. Paul : FEBS Lett. 9, 242 (1970).

Goldberg, A.R.: Cell 2, 95 (1974).

Gonzalez, C.A. and K.R. Rees: Biochim. Biophys. Acta 395, 361 (1975).

Hewisch, D. and L. Burgoyne: Biochem. Biophys. Res. Commun. 52, 504 (1973).

Hnilica, L.S., M.D. McClure and T.C. Spelsberg: In: Histones and Nucleohistones; ed. D.M.P. Phillips (Plenum Press, New York) p. 187 (1971).

Huang, R.C. and J. Bonner: Proc. Nat. Acad. Sci. U.S.A. 54, 960 (1965).

Kleinsmith, L.J., J. Heidema and A. Carrol: Nature 226, 1025 (1970).

Kornberg, R.D.: Science 184, 868 (1974).

Kornberg, R.D. and J.O. Thomas: Science 184, 865 (1974).

Kostraba, N. and T.Y. Wang: Exp. Cell Res. 80, 291 (1973).

Krause, M.O. and B. Inasi : Arch. Biochem. Biophys. 164, 179 (1974a).

Krause, M.O., L.J. Kleinsmith and G.S. Stein: Exp. Cell Res. 92, 164 (1975a). 
'Krause, M.O., L.J. Kleinsmith and G.S. Stein: Life Sci. 16, 1047 (1975b).

Krause, M.O., and G.S. Stein: Biochem. Phyphys. Res. Commun. 59, 796 (1974b).

Krause, M.O. and G.S. Stein: Exp. Cell Res. 92, 175 (1975c).

Krause, M.O., B.Y. Yoo and L. MacBeath: Arch. Biochem. Biophys. 164, 172 (1974c).

Lin, J., C. Nicolini and R. Baserga: Biochemistry 13, 4127 (1974).

Lowry, O.H., N.J. Rosebrough, A.L. Farr and R.S. Randall: J. Biol. Chem. 193, 265 (1951)

Noll, M.: Nature 252, 249 (1974).

Olins, A. and D. Olins: Science 181, 330 (1974).

Panyim, S. and R. Chalkley: Biochemistry 8, 3972 (1969).

Paul, J., R.S. Gilmour, N. Affara, G. Birnie, P. Harrison, A. Hell, S. Humphries, J. Windass and B. Yound: Cold Spring Harbor Symp. Quant. Biol. 38, 885 (1973).

Rill, R. and K. van Holde: J. Biol. Chem. 248, 1080 (1973).

Sakiyama, T. and B.W. Burge: Biochemistry, 11, 1366 (1972).

Spelsberg, T.C. and L. Hnilica: Biochem. J. 120, 435 (1970).

Stein, G.S. and R. Baserga: Adv. Cancer Res. 15, 287 (1972a).

Stein, G.S. and J. Farber: Proc. Nat. Acad. Sci. U.S.A. 69, 2918 (1972b).

Stein, G.S., G. Hunter and L. Lavie: Biochem. J. 139, 71 (1974a).

Stein, G.S., W.D. Park, C.L. Thrall, R.J. Mans and J.L. Stein: Nature (in press).

Stein, G.S., T.C. Spelsberg and L.J. Kleinsmith: Science 183, 817 (1974b).

Stein, G., J. Stein, C. Thrall and W. Park: In: Chromosomal Proteins and Their Role in the Regulation of Gene Expression; eds. G.S. Stein and L.J. Kleinsmith et al. (Academic Press, New York) (1975).

Stein, G.S. and C.L. Thrall: FEBS Lett. 32, 41 (1974).

Teng, C., C. Teng and V.G. Allfrey: J. Biol Chem. 246, 3597 (1971).

Weintraub, H. and E. van Lente: Proc. Nat. Acad. Sci. U.S.A. 71, 4249 (1974).

Yogeeswaran, G., R. Sheinin, J.R. Wherrett and R.K. Murray: J. Biol. Chem. 247, 5146 (1972).

Zardi, L., J.C. Lin and R. Baserga: Nature New Biol. 245, 211 (1973). 